\title{
The Relations between Superheroes and Their Enemies as an Analogy of Binary Opposition Relationship
}

\author{
Sayid Mataram ${ }^{1}$, Deny T Ardianto ${ }^{2}$ \\ \{sayidmataram@staff.uns.ac.id ${ }^{1}$ \} \\ 1,2 Universitas Sebelas Maret, Surakarta, Indonesia
}

\begin{abstract}
The fight between the good and evil is a relationship that has existed in stories since the ancient times. This relation is one form of binary opposition relationships. The binary opposition is a social phenomenon that occurs in the comic universe society, which is commonly found in comics with superhero action genre. Thus this research applied hermeneutical phenomenology, which seeks to observe and then interpret a condition on a particular phenomenon. In the modern world, the binary opposition relationship is still ongoing and can be found in the new media such as the comic books. In the comics, there is a relationship between protagonist and antagonist characters divided based on the time of appearance and based on the number of individuals involved. In addition, the binary opposition relationship between comic characters often leads to their popularity and existence as characters representing both the good and the evil side as a reaction from fans who seeks to fulfill their curiosity towardthe comic characters.
\end{abstract}

Keywords: Comic, Superhero, Binary Opposition, Narrative Structure

\section{INTRODUCTION}

Almost every ethnic group in the world can be said to have folklore that raises the story of heroism, stories that tells about struggle between a character who represents the good side against a character who represents the evil side. The story of folklore in various nations is usually conveyed from generation to generation, and to the new generation. The classic story about the battle between the good side and the evil side is always developing and always presented in new method and media.According to Strauss,folklore, or what he referred as mythsfrom many parts of the world, bears a resemblance of being built by the same constructs of thought. Through the systematic application of anthropological structure analysis, we can find folklore variants which later become a series in the form of permutation groups. The variant gives rise to a symmetrical, but opposite structure. If the first sequence of folklore is chaotic (chaos), after it is structured, harmony (cosmos) is found [1]. Chaos and cosmos relations are representations of a relationship form that cannot be separated from one another. Or in a structurural context, it can be said as aform of binary opposition. Binary opposition is a structural relation with a comparative approach to dichotomy [2]. In everyday culture the dichotomies in binary opposition relations are manifested in various representations, such as sacred and profane relationships, day and night, men and women, and so on 
One of today's modern media is comics, which is a form of print media platform which later also develops into a form of digital media platform. Comics are a series of images and other symbols that are positioned in a certain order to convey information or aesthetic responses from their readers[3]. The narrative-based comics presented by comic artists to its readers have several genres, in which one of them is the super hero action genre. Superhero comics are comics that tell the journey of a superhero or more, in carrying out their mission to fight for good values and the public interest [4]. Popular comics with this genre are currently published by DC and Marvel, which are marked by the achievement of popularity through the adaptation of superhero stories from comics to films.

Super-hero comic books tend to focus on the exploits of one character and her or his supporting cast (e.g., Wonder Woman, Spawn, and Incredible Hulk) or a team of superheroes (e.g., Justice League, X-Men, and Wild C.A.T.S.) [5]. In this genre, superheroes are presented as a representation of the good side against their enemies as the representations of the evil side. Superhero figuresarefictional character, who are usually portrayed as the defender of righteousness or the good side. Superheroes may take the form of either human or non-human with super powers. According to Coogan, "a superhero is" a heroic character "with a mission, super powers and a specific, recognizable identity" [4]. Once we get to the appearance of the first Comic Action in 1938, starring the new hero Superman, we reached a contentious moment in the comics history. The tremendous popularity and influence of the superhero genre has served both as background and alterations to contemporary work in comics [6].

This research takes the case of superhero groups and their enemies, referring to popular superhero comics, namely from the publishers of Marvel and DC, as a form of representation of binary opposition from the good and evil sides, so that it can be explored regarding the variety and forms of relations that emerge and the effects of the relation.

\section{METHOD}

This research is a hermeneutic phenomenology research, which seeks to examine, understand, and interpret a phenomenon to achieve a reality [7]. Samples in this study were taken randomly with purposive sampling technique. The objects in this study are superhero characters and their enemies in the comic action superhero genre, especially from Marvel and DC publishers. Comics from the two publishers currently dominate the popularity and market trends of the world comics in the superhero genre. The analysis in this study was carried out through a structural approach to examine, understand, then interpret the relationship between superhero comic characters and their enemies as an analogy to the form of binary opposition structures. In interpreting these relations, it is necessary to see or analyze the content of the comics, so that it also uses the content analysis method in this study. Content analysis is a research technique for making replicable and valid inferences from texts to the context of their use [8].

\section{RESULT AND DISCUSSION}

Comic is one form of modern media and popular culture which is basically a means to tell a story. Comics have structures that consist of visual structures and non-visual structures that contain narrative elements arranged in certain patterns [9]. Narrative elements and patterns in 
comics convey messages in a similar way to the conventional method of oral storytelling. Almost all patterns begin in situations that are chaotic or those that are leading to chaos, and end with certain conditions that are dominated by cosmos conditions. The comparative element between oral and print media (comics) basically lies in the type of technicality and the media. The development of technicality and media bears influence especially to the visualization of condition and the characters presented.

One of these genres is the action genre that focuses on the heroic stories of superheroes in fighting crime in the comic-verse. The story in this genre always brings out good characters against evil characters. Characters in comics are created as visualisations from the narrative that is responsible for bringing fractions of messages to comic readers. Thus, to get a complete message, the characters in the comic must cooperate with other characters and other visual elements of the comics. Scott McCloud states that there are three benchmarks to make characters look alive and convincing, namely the character designs, facial expressions, and body language (gesture), and for a character to be interesting, it has to seemingly have souls, characteristics, and expressive attitudes [10].

As a form of binary opposition relations, the good and evil characters will not be meaningful if only one is raised, so that the relation between the two characters from the opposite sides must be present. In literature, for example in novels or short stories, binary opposition often serves as framework that sustains the structure of the story. There are antagonist-protagonist, good-evil, host-guests, etc. [11].

The characters representing the good side are presented by superhero characters who carry a mission to enforce justice or protect the weak. The superhero character in the action is presented alone, with a colleague who are referred to as sidekick (like Batman and Robinor Ironman and War Machine), or with a team of other superheroes such as the Justice League or in cross over comics (comics that display characters from other comics even from other publishers). Hall and Lucal [5] mentioned that superhero comics present good versus evil (or good versus good until they learned they were fighting the same enemy). Characters that represent the evil side are presented by enemy figures of the superheroes, whose mission is to disturb the stability of the imaginary world conditions in the comics. This missionis sometimes carried out by a main enemy, along with his subordinates, or a major enemy group. It can be said that superhero comics present stories involving a character or group of superheroes, in which the amount of the involvement also applies to the evil character that he or the are fighting against.

The figure of a superhero character portrayed narratively is an extraordinary character with several factors producing superpowers, among others because it is the result of divine origin or their myths, alien inheritance, magic, access to sophisticated technology, mimicking the extraordinary abilities shown in the animal world, or because of magic concoctions [11]. Aside from being found in the protagonist's character, the same thing applies to antagonistic characters or later known as super villains.

The figure of a superhero character portrayed narratively is an extraordinary character with several factors producing superpowers, among others because it is the result of divine origin or their myths, alien inheritance, magic, access to sophisticated technology, mimicking the extraordinary abilities shown in the animal world, or because of magic concoctions [12]. People refer to superheroes as modern representations of God or at least refer to superheroes' stories as "modern mythology", this is because they have an identification with the relationship of heroes to past stories [13]

The relationship of superheroes with their enemies is categorized into two types based on the time of appearance and based on the number of individuals involved. Based on the time of 
appearance based on the appearance of the characters in each episode of the comic published. In this connection it is divided into eternal relationships and temporary relationships.

\subsection{Eternal relationship}

This relation occurs when superhero characters always fight the same enemy in each episode. It can even be presented as an indication that if one of the characters appears, the counter character will also appear. For example Captain America will fight the Red Skull, Professor X with the X-Men group will fight Magneto with the Brotherhood group of evil Mutant.

\subsubsection{Temporary relationship}

In this relation, there are different characters or changes in each different episode. This relationship also applies to comics with crossover stories. This relation can be divided into several types, whic are:

\subsubsection{Temporary enemy}

This relation presents different enemies in each episode, both on the main enemy character or companion enemy in the form of subordinates or colleagues who are on the same level as the main enemy. This makes one superhero character appear to have many big enemies, for example Batman has enemies like Joker, Penguin, Catwoman, Twoface or Spiderman with Green Goblin, Dr. Octopus, Black Cat, Kingpin, Rhino.

\subsubsection{Temporary superhero}

This relation presents different superheroes in each the episode, both as the main superhero character, guest superhero, or sidekick of the main superhero. For example in the presence of Wolverine and Dare Devil as superheroes from other comics in Spiderman comics.

Whereas the relationship based on the number of individuals involved in each meeting is divided into the involvement of superheroes, their sidekicks, main enemies, and their subordinates. In this relation it is divided into nine relationship patterns, namely:

- The relation of a single superhero with a single enemy; for example Captain America with the Red Skull, Superman with Lex Luthor, Batman with the Joker, Professor X with Magneto.

- A single superhero relation with the main enemy and his men; for example Captain America with the Red Skull and Hydra or Batman forces against the Joker and his clown army.

- Relation of a single superhero with the main enemy group; for example Spiderman against Venom in collaboration with CarnageorBatman against Superman which is being controlled by Poison Ivy.

- Relation of the superhero and his sidekick with a single enemy; for example Batman and Robin against the Joker.

- Relation of the superhero and his sidekick with the main enemy and his men; for example Batman and Robin when fighting a group of Jokers, Penguins, and other enemies.

- Relation of the superhero and his sidekick with his main enemy group; this happens if the superhero and his sidekick fight conspiracy between the main criminals.

- Relation of superhero groups with single main enemies; for example the X-Men group against Magnetoor the Fantastic Four against Dr.Doom.

- Relation of A superhero group with single main enemies and their men; for example Avenger against Thanos and his men. 
- Relation of superhero groups with major enemy groups; for example the X-Men group against the Brotherhood of Evil Mutant group.

Comic worldis a fictional world inspired by the real world. However, not all elements are straightforwardly adopted because there are slightly different laws in comics. This also applies in binary opposition relation between the good side and the evil side. In the real world, a hero as a representation of the good side will surely have many fans while the opposite will apply to the enemies. But in comics, both superhero characters and villain or enemy figures have fans.

This happened because the enemy's popularity is balanced with the superhero's popularity as their opponents. For example, the Joker character (which first appeared in the April 25, 1940 Batman comic) as the mortal enemy of Batman, this character is popular because it has a strong psychological side and very many visuals created by artists and fans to create the Joker's new physical model or referred to as a fanart. The binary opposition relation in this case is able to lift the character's image, so that both superheroes and their opponents are able to achieve a high level of positivity in the minds of comic readers.

Likewise, for example with the evil character Venom (which first appeared in the Amazing Spierman \# 299 comic on May 1988, Venom began with the introduction of Alien Simbiote characters in the Amazing Spiderman \# 252 comic), as a character formed by Eddi Brock character who is infected with symbiote creatures. This character started out as an enemy to Spiderman, then presented in a pin-up comic and even turned into an anti-hero character. Another case of the anti-hero superhero that draws from the popularity of supervilians is the Suicide Squad comic (which first appeared in 1959, with a modern version that first appeared in 1987) consisting of Batman's strong enemies. These supervillain unite in a group named after their comics to fight other criminals. This condition also represents a binary opposition relationship from chaotic conditions of the evil side character that is identical to evil, turning into a hero who create harmonious conditions.

The effect of the binary opposition relation is the popularity and the existence of comic characters both representing the good or the evil sides. This popularity raises fans' demand for the characters to be explored more. Thus there were many pin-up superheroes comics produced. For example, in the X-Men group there is an alterego character of Wolverine (which appeared in the Giant-Size X-Men \# 1 comic in 1975) which was later produced in its own comic series so fans were taken to see who the character really was and how the story of his adventure outside the X-Men group. Increased fan interests then also lead to the demandto see the superheroes working together and forming affiliations such as the Justice League from the DC Universe and Avenger from the Marvel Universe. The superheroes popularity not only leads to the demand to unite them, but also to the demand to break them apart such as the civil war comic event (2006-2007) in which the heroes from the Marvel universe were divided into two opposing parties; the pro-IronMan group against the pro-Captain America. Even in the comic, the supervilain, as a term for the main enemy of the superhero, is also involved in supporting the split of superhero groups.

One real form of fans' appreciation for comis characters' popularity is presented through cosplay events. A cosplay event is an attempt by the fans of imaginary characters to fulfill their dreams to act as if they were in the comic universe. The word cosplay is derived from two English words of costume and play. This term is used to refer to the activities of young people who wear costumes similar to the character-styles in Japanese manga or comics and Japanese anime or cartoons [14], which have also expanded to the Western comics, animation, and films. In cosplay events, fans are spoiled by people who tranform to their favourite 
characters using costumes, make up, or other accessories to look the same as the imaginary character.

The superhero comic that first appeared and later inspired the emergence of comics with similar stories is the Superman comic (1938). This means that superhero comics were born before the Babyboomer generation and long before the $\mathrm{X}, \mathrm{Y}$, and $\mathrm{Z}$ generations were born. The original premise of the superhero comic generation was limited to fighting between the good and evil. This comic premise then develops along the next generation, which is based on curiosity for something that already exists. This curiosity, for example, causes superhero leads to some events and story lines in the comics such ass how superheroes battle each other in one universe (such as,CivilWar from the Marvel Universe), how superheroes die (for example in Death of Superman) or how they rise from the dead, as well as other background or side story of a character. The condition of changing the premise of this story is influenced by the models of different generations, young people (millennial) are more likely to get bored and want something challenges or changes immediately [15]. The story premise then developed by exploring things that are not revealed in the comics that existed before.

\section{CONCLUSION}

Comics are a new medium in storytelling. Both print and digital comic platforms are composed of certain narrative patterns. The narrations in the comics lead to the emergence of various genres, one of which is the superhero action genre. The superhero genre is a contemporary form of the good against evil story, in which the relation between the good side and the evil side is one form of binary opposition relations. This relation requires involvement from both sides to react to each other, then the characters from both sides will not be meaningful without the other. Binary opposition relation also applies in the form of narratives, from chaotic conditions to cosmos (harmonious) conditions. The character that represents the good side is presented by a superhero character who carries a mission to enforce justice or protect the weak. While the character that represent the evil side is presented by enemy figure of the superhero who carries a mission to disturb the stability of the imaginary world conditions in the comics. The evil mission is sometimes carried out by a main enemy, along with his or her subordinates, or the main enemy group. The relationship of superheroes with their enemies as a form of binary opposition relation is categorized into two, namely based on the time of appearance and based on the number of individuals involved.

In the comic there is a phenomenon that both superhero figures and criminal figures as the enemies have fans. This happens because the popularity of the enemy is balanced with the popularity of the superheroes as their opponents. The effect of the binary opposition relation leads the popularity and the existence of comic characters both those that represent the good side or the evilcaused by fans reactions that demand to fulfill their curiosity towards the comic characters. In addition, this popularity also leads to the commercialization of the comic characters.

The premise of battle between good and evil in superhero comics has been presented since the first appearance of superheroes, which is before the babyboomer era. This premise has also developed in the subsequent generations. In addition to the story development, the comics also develop in terms of visualization and media. 


\section{REFERENCES}

[1] Suhartono, B. Yulianto, and A. Ahmadi, "Cerita Rakyat di PulauMandangin: KajianStrukturalAntropologiLévi Strauss," JurnalJurusanSastradanBahasa Indonesia, vol.23, no.4, pp. 304-311, 2010.

[2] S. Subiantoro, "AntropologiSeniRupa: Teori, Metode, danContohTelaahAnalitis," Surakarta: UNS Press, 2011

[3] S. McCloud, "Understanding Comic," Jakarta: PT GramediaPustakaUtama, 2001

[4] R.A. Kurniawan, "KebudayaanLokalDalamKomikSupehero Indonesia," INVENSI, vol. 2, no.1, pp. 9-15, 2017.

[5] K.J. Hall and B. Lucal, "Tapping IntoParalel Universes: Using Superhero Comic Books in Sociology Courses," Teaching Sociology, vol. 27, no.1, pp. 60-66, 1999.

[6] A. Freedman, "Comics, Graphic Novels, Graphic Narrative: A Review," Literature Compas, Blackwell Publishing Ltd, 2011.

[7] Sumartono, "Metodologi Penelitian Kualitatif Seni Rupa \& Desain," Jakarta: Pusat Studi Reka Rancang Visual dan Lingkungan Universitas Trisakti, 2017.

[8] K. Krippendorff, “Content Analysis,” USA: Sage Publication Inc., 2004.

[9] S. Mataram, "Struktur Visual Komik," Surakarta: UNS Press, 2018

[10] S. McCloud, "MembuatKomik," Jakarta: PT GramediaPustakaUtama, 2007.

[11] M. Ungkang, "Dekonstruksi Jaques Derrida sebagai Strategi Pembacaan Teks Sastra," Jurnal Pendidikan Humaniora, vol.1, no.1, pp.30-37, 2013.

[12] M. DiPaolo, "War, Politics, and Superheroes," North Carolina: McFarland \&Comapany Inc., 2011.

[13] T.R. Wandtke, "The meaning of Superhero Comic Books", North Carolina: McFarland \&Comapany Inc., 2012

[14] R. Rastati, "Media dan Identitas: Cultural Imperialism Jepang Melalui Cosplay (Studi terhadap Cosplayer yang Melakukan Crossdress)," Jurnal Komunikasi Indonesia, vol.1, no.2, pp.41-52, 2012.

[15] J.G. Sujansky and Jan Ferry-Reed, "Keeping The Millenials," New Jersey: Wiley \& Sons Inc., 2009. 